\title{
Az elmúlt négy év olvasottságáról
}

\author{
Reading statistics
}

doi: 10.24365/ef.v60i5.551

Vilmon Gyula-nívódíjas folyóiratunk idén ünnepli fennállásának 60. évfordulóját, ennek apropójából jelentetjük meg a Jubileumi lapszámot. Öt cikkben dolgoztunk fel a lap legkorábbi, 1960-as és 1970-es években megjelent számaiból közleményeket.

A jubileum mellett a mostani lapszámban egy tematikus blokk is található, kilenc írás szól a „Nyíregyháza életminősége - Háztartáspanel” kutatássorozat eredményeiről.

A látogatói és olvasottsági statisztikákat az elmúlt 4 évben már megszokott módon mutatjuk be, látható, hogy a lap népszerúsége a szakemberek körében töretlen.
Az ábrán látható a weboldalunk látogatóinak havi száma (már második alkalommal 11 ezer feletti), illetve az átlagos napi értékek. Az első elektronikus lapszám megjelenése óta - 2016. április - mindkét adat megsokszorozódott.

A 10 „legérdekesebb”cikk közé bekerült ketto, az előző lapszámban megjelent írás is, a többi TOP10es listán nincs jelentős változás.

Várjuk hozzászólásaikat, javaslataikat a cikkekhez bejelentkezés után a weboldalon, és kövessék a lapot a facebook-on is.

1. ábra: A folyóirat honlapját havonta, illetve naponta átlagosan meglátogatók száma

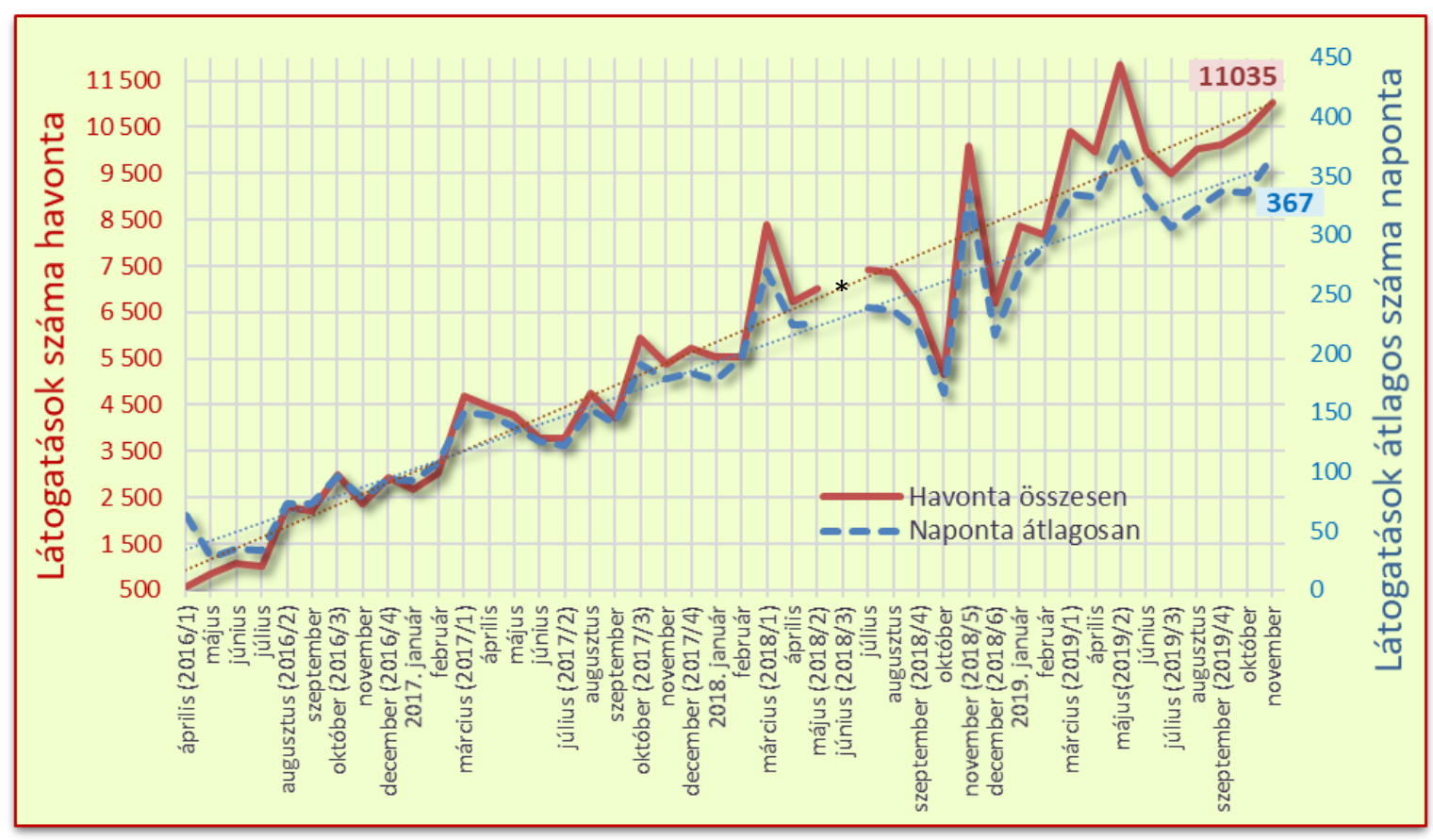

* nincs adat 


\begin{tabular}{|c|c|c|c|}
\hline $\begin{array}{l}\text { Megtekin- } \\
\text { tések száma }\end{array}$ & Közlemény címe & Szerző́k & Lapszám \\
\hline \multicolumn{4}{|c|}{ ÖSSZEFOGLALÓ } \\
\hline 760 & A kortársbántalmazás (bullying) mint népegészségügyi probléma & Várnai D, Zsíros E, Németh Á & 2016. 4. szám \\
\hline 751 & Hazai egészség-pillanatkép, 2017 & Vitrai J, Bakacs M, Varsányi P & 2017. 4. szám \\
\hline 748 & Egészséges életmóddal kapcsolatos kutatások a hazai iskolákban & Járomi É, Szilágyi K, Vitrai J & 2016. 1. szám \\
\hline 610 & $\begin{array}{l}\text { Kortárs egészségfejlesztési programok gyermekek és fiatalok körében a hazai és a nemzetközi } \\
\text { szakirodalom tükrében - Szisztematikus áttekintés }\end{array}$ & Lukács-Jakab Á et al. & 2018. 1. szám \\
\hline 568 & $\begin{array}{l}\text { A gyógytestnevelés jelentősége a szekunder rehabilitáció és egészségfejlesztés folyamatában, } \\
\text { megújulásának szükségessége, irányai }\end{array}$ & Simon I, Kajtár G & 2018. 1. szám \\
\hline 563 & $\begin{array}{l}\text { A 2015/2016. tanév országos fittségmérési eredményei a Nemzeti Egységes Tanulói Fittségi } \\
\text { Teszt (NETFIT®) alapján }\end{array}$ & Csányi T, Kaj M & 2017. 4. szám \\
\hline 544 & A magyarországi egészségértés nemzetközi összehasonlításban & Koltai J, Kun E & 2016. 3. szám \\
\hline 543 & $\begin{array}{l}\text { Az egészségügyi ellátáshoz való hozzáférés területi egyenlőtlenségeinek vizsgálata az akut } \\
\text { miokardiális infarktus okozta halálozás adatainak felhasználásával }\end{array}$ & Uzzoli A, Vitrai J, Tóth G & 2017. 3. szám \\
\hline 526 & Az iskolai egészségfejlesztés hazai és nemzetközi szemléletének bemutatása & Járomi É, Vitrai J & 2017. 1. szám \\
\hline 523 & Egészségfejlesztő program középiskolások körében - Az alapállapot felmérés eredményei & Pénzes G, Bíró É & 2018. 4. szám \\
\hline \multicolumn{4}{|c|}{ TELES KÖZLEMÉNY } \\
\hline 3182 & A csecsemőkori allergia-megelőzés korszerú irányelvei és lehetőségei & Réthy $\mathrm{A}$ & 2017. 1. szám \\
\hline 1286 & Egészséges életmóddal kapcsolatos kutatások a hazai iskolákban & Járomi É, Szilágyi K, Vitrai J & 2016. 1. szám \\
\hline 799 & Magyarország népegészségügyi rendszere és egészségfejlesztéssel foglalkozó szervezetei & Túri G et al. & 2018. 2. szám \\
\hline 750 & Hazai egészség-pillanatkép, 2017 & Vitrai J, Bakacs M, Varsányi P & 2017. 4. szám \\
\hline 665 & $\begin{array}{l}\text { Energiaital fogyasztási szokások és egészségtudatosság a felsőfokú képzésben résztvevő hallga- } \\
\text { tók körében }\end{array}$ & $\begin{array}{l}\text { Dojcsákné Kiss-Tóth É, Kiss- } \\
\text { Tóth E }\end{array}$ & 2018. 4. szám \\
\hline 651 & OKOSTÁNYÉR ${ }^{\oplus}$ - új táplálkozási ajánlás a hazai felnőtt lakosság számára & Szúcs Zsuzsanna & 2016. 4. szám \\
\hline 520 & A magyarországi egészségértés nemzetközi összehasonlításban & Koltai J, Kun E & 2016. 3. szám \\
\hline 496 & $\begin{array}{l}\text { Összefoglaló „A munkahelyi egészségfejlesztés általános szervezeti megvalósítására vonatkozó } \\
\text { szakmai útmutató”-ról }\end{array}$ & Solymossy J, Koós T & 2016. 3. szám \\
\hline 487 & Amerikai Táplálkozási Ajánlás 2015-2020 - rövid ismertetés & Fekete K, Henter I & 2016. 2. szám \\
\hline 476 & A fizikai aktivitás, mint egészségbefektetés & Gabnai Z et al. & 2019. 1. szám \\
\hline \multicolumn{4}{|c|}{ "ÉRDEKESSÉG" } \\
\hline 3,23 & A csecsemőkori allergia-megelőzés korszerú irányelvei és lehetőségei & Réthy A & 2017. 1. szám \\
\hline 1,76 & A fizikai aktivitás, mint egészségbefektetés & Gabnai Z et al. & 2019. 1. szám \\
\hline 1,54 & $\begin{array}{l}\text { Energiaital fogyasztási szokások és egészségtudatosság a felsőfokú képzésben résztvevő hallga- } \\
\text { tók körében }\end{array}$ & $\begin{array}{l}\text { Dojcsákné Kiss-Tóth É, Kiss- } \\
\text { Tóth E }\end{array}$ & 2018. 4. szám \\
\hline 1,40 & Magyarország népegészségügyi rendszere és egészségfejlesztéssel foglalkozó szervezetei & Túri G et al. & 2018. 2. szám \\
\hline 1,05 & Cikkismertetés: Népegészségügy 3.0 & Vitrai J & 2019. 4. szám \\
\hline 1,05 & Hazai egészség-pillanatkép, 2017 & Vitrai J, Bakacs M, Varsányi P & 2017. 4. szám \\
\hline 0,98 & Egészséges életmóddal kapcsolatos kutatások a hazai iskolákban & Járomi É, Szilágyi K, Vitrai J & 2016. 1. szám \\
\hline 0,93 & Alternatív dohánytermékek használata fesztiválon résztvevő fiatal felnőttek körében & Torma A et al. & 2019. 4. szám \\
\hline 0,92 & Tematikus cikkválogatás az iskolai egészségfejlesztés területéről & szerkesztőség & 2019. 4. szám \\
\hline 0,89 & A gyermekkori elhízás népegészségügyi vonatkozásai & Kovács AV & 2018. 4. szám \\
\hline
\end{tabular}

